\title{
Variable Effects of Goitrogens in Inducing Precocious Metamorphosis in Sea Lampreys (Petromyzon marinus)
}

\author{
RICHARD G. MANZON, JOHN A. HOLMES, AND JOHN H. YOUSON* \\ Department of Zoology and Division of Life Sciences, University of Toronto at \\ Scarborough, Toronto, Ontario, M1C 1A4 Canada
}

\begin{abstract}
The ability of different goitrogens (anti-thyroid agents) to induce precocious metamorphosis in larval sea lampreys (Petromyzon marinus) was assessed in four separate experiments. Two of these goitrogens (propylthiouracil [PTU] and methimazole [MMI]) are inhibitors of thyroid peroxidase-catalyzed iodination, and three (potassium perchlorate $\left[\mathrm{KClO}_{4}\right]$, potassium thiocyanate $[\mathrm{KSCN}]$, and sodium perchlorate $\left[\mathrm{NaClO}_{4}\right]$ ) are anionic competitors of iodide uptake. Because, theoretically, all of these goitrogens prevent thyroid hormone (TH) synthesis, we also measured their influence on serum concentrations of thyroxine and triiodothyronine. All goitrogens except PTU significantly lowered serum TH concentrations and induced metamorphosis in some larvae. The incidence of metamorphosis appeared to be correlated with these lowered $\mathrm{TH}$ concentrations in that $\mathrm{KClO}_{4}, \mathrm{NaClO}_{4}$, and MMI treatments resulted in the lowest serum TH concentrations and the highest incidence of metamorphosis in sea lampreys. Moreover, fewer larvae metamorphosed in the $\mathrm{KSCN}$ and low- $\mathrm{KClO}_{4}$ treatment groups and their serum $\mathrm{TH}$ concentrations tended to be greater than the values in the aforementioned groups. MMI treatment at the concentrations used $(0.087$ and $0.87 \mathrm{mM})$ was toxic to $55 \%$ of the exposed sea lampreys within 6 weeks. The potassium ion administered as $\mathrm{KCl}$ did not alter serum $\mathrm{TH}$ concentrations or induce metamorphosis. On the basis of the results of these experiments, we have made the following conclusions: (i) In general, most goitrogens other than PTU can induce metamorphosis in larval sea lampreys, and this induction is coincident with a decline in serum TH concentrations. (ii) The method by which a goitrogen prevents TH synthesis is not directly relevant to the induction of metamorphosis. (iii) PTU has variable effects on TH synthesis and metamorphosis among lamprey species. (iv) Unlike in protochordates, potassium ions do not induce metamorphosis in sea lampreys and are not a factor in the stimulation of this event. J. Exp. Zool. 289:290-303, 2001. (C) 2001 Wiley-Liss, Inc.
\end{abstract}

The stimulatory role of the thyroid gland on the onset and progression of amphibian metamorphosis were first described by Gudernatsch ('12). Following this initial report, several studies have shown that a rise in serum thyroid hormone $(\mathrm{TH})$ titers (thyroxine $\left[\mathrm{T}_{4}\right]$ and triiodothyronine $\left[\mathrm{T}_{3}\right]$ ), from prometamorphosis to their peak at metamorphic climax, is critical to metamorphosis. Furthermore, treatment with exogenous TH stimulates precocious metamorphosis, and anti-thyroid agents (goitrogens) can prevent or dramatically delay the onset of spontaneous metamorphosis in amphibians. The stimulatory role of $\mathrm{TH}$ on metamorphic development has been observed in most amphibians (for review see Dodd and Dodd, '76; White and Nicoll, '81; Galton, '83) and bony fishes (flat fishes, eels, and tarpons) (Just et al., '81; Inui et al., '94) studied to date. Within the vertebrate subphylum, the Petromyzon- tiformes (lampreys) represent the one exception to this trend (Youson, '97).

The nature of the involvement of $\mathrm{TH}$ in lamprey metamorphosis has yet to be resolved; however, some data are consistent with the idea that their function differs from that observed in other vertebrates. Serum TH concentrations in the sea lamprey (Petromyzon marinus) increase gradually

R.G. Manzon's current address: Department of Biology, University of Michigan, Ann Arbor, MI 48109-1048.

J.A. Holmes' current address: Axelrod Institute of Ichthyology, Department of Zoology, University of Guelph, Guelph, Ontario, N1G 2W1, Canada.

Grant sponsor: Natural Sciences and Engineering Research Council of Canada (NSERC); Grant number: A5945. Grant Sponsor: Great Lakes Fisheries Commission.

*Correspondence to: John H. Youson, Division of Life Sciences, University of Toronto at Scarborough, 1265 Military Trail, Toronto, Ontario, M1C 1A4, Canada. E-mail: youson@scar.utoronto.ca

Received 22 May 2000; Accepted 27 October 2000 
throughout the 3- to 7-year larval period, peak prior to the onset of metamorphosis, and decline sharply concomitant with the first external signs of metamorphosis (for review see Youson, '97). Throughout metamorphosis and for the remainder of the sea lamprey life cycle, serum TH concentrations are maintained at these reduced concentrations. The universal nature of this decline in serum $\mathrm{TH}$ concentrations at the onset of metamorphosis in lampreys is supported by similar observations in other lamprey species. Significant declines in serum $\mathrm{T}_{4}$ and $\mathrm{T}_{3}$ concentrations from larval values were observed in the southern hemisphere lamprey, Geotria australis (Leatherland et al., '90), and the American brook lamprey, Lampetra appendix (Holmes et al., '99), by stages 1 and 2 of metamorphosis, respectively.

Lampreys also differ from other vertebrates in that goitrogens induce rather than inhibit metamorphosis. Hoheisel and Sterba ('63) first reported the induction of an incomplete metamorphosis in Lampetra planeri following exposure to the goitrogen potassium perchlorate $\left(\mathrm{KClO}_{4}\right)$. The induction of a complete metamorphosis following treatment with $\mathrm{KClO}_{4}$, sodium perchlorate $\left(\mathrm{NaClO}_{4}\right)$, propylthiouracil (PTU), or thiourea was later reported in a series of preliminary studies on Lampetra reissneri (Suzuki, '86, '87, '89). More recent studies conducted at a time of year when spontaneous metamorphosis does not occur resulted in the incomplete metamorphosis of $P$. marinus (Holmes and Youson, '93; Manzon and Youson, '97; Manzon et al., '98) and $L$. appendix (Holmes et al., '99). In these studies, $\mathrm{KClO}_{4}$-treated larvae had serum $\mathrm{T}_{4}$ and $\mathrm{T}_{3}$ concentrations that were $18-80 \%$ and $72-$ 95\% lower than control values, respectively. The observed declines in serum $\mathrm{TH}$ concentrations at the onset of both $\mathrm{KClO}_{4}$-induced and spontaneous metamorphosis are consistent with the idea that these declines may be involved in the initiation of metamorphosis (Youson et al., '95; Manzon et al., '98; Holmes et al., '99). In contrast, PTU did not induce metamorphosis in G. australis (Leatherland et al., '90) or L. appendix (Holmes et al., '99) despite its ability to significantly lower serum $\mathrm{TH}$ concentrations. Serum $\mathrm{T}_{4}$ and $\mathrm{T}_{3}$ concentrations were reduced by $95 \%$ and $75 \%$, respectively, in $G$. autralis and $54 \%$ and $80 \%$, respectively, in L. appendix.

The correlation between lowered serum TH concentrations and the induction of metamorphosis in goitrogen-treated lampreys indicates that high TH titers may have an anti-metamorphic effect, preventing the onset of metamorphosis. Alterna- tively, very low TH titers may permit or even trigger the onset of metamorphosis if the appropriate physiological and environmental conditions have been met (Youson, '97; Manzon and Youson, '99). The absence of induced metamorphosis in PTUtreated lampreys of two different species, however, provides compelling evidence to challenge these notions. Whether the induction of precocious metamorphosis is due to a decline in serum TH concentrations or to a phenomenon related to extrathyroidal effects of certain goitrogens (i.e., $\mathrm{KClO}_{4}$ ) remains to elucidated. Alternatively, PTU may have extrathyroidal effects that are either inhibitory to metamorphosis or toxic to lampreys. Perhaps the ability of a particular goitrogen to induce metamorphosis is related to the mechanism through which it inhibits TH synthesis.

In the current study we attempted to resolve some of the aforementioned uncertainties surrounding goitrogen-induced metamorphosis in lampreys. Our approach was to assess the ability of various goitrogens to lower serum TH concentrations and induce precocious metamorphosis in larval sea lampreys. This study consisted of a series of four experiments in which larval sea lampreys of different sizes were exposed to various goitrogens. The goitrogen treatments included three anionic competitive inhibitors of iodide uptake $\left(\mathrm{KClO}_{4}, \mathrm{NaClO}_{4}\right.$, and potassium thiocyanate, $\mathrm{KSCN}$ ) and two goitrogens that inhibit the process of thyroid peroxidase-catalyzed iodination (PTU and methimazole, MMI) (Gentile et al., '95). In addition, one experiment was designed to examine the effects of potassium ions $\left(\mathrm{K}^{+}\right)$associated with $\mathrm{KClO}_{4}$ and $\mathrm{KSCN}$ treatment on the induction of metamorphosis in lampreys, since $\mathrm{K}^{+}$ ions induce metamorphosis in larval protochordates (Degnan et al., '97).

\section{MATERIALS AND METHODS}

\section{Experimental protocols and animals}

This study consisted of four experiments conducted in different years, at a time of year that spontaneous metamorphosis does not occur; metamorphosis occurs in sea lampreys between July and October (Potter et al., '78). A description of the procedures for animal collection and experimental setup, monitoring and maintenance used in all four experiments follows. Any variations from these procedures are provided in the detailed description of each individual experiment. Larval sea lampreys were collected from various streams in the Great Lakes drainage basin (Canada and 
United States of America) in the spring and summer months using electrofishing equipment. Sea lampreys were transported to the University of Toronto at Scarborough and housed in large fiberglass aquaria supplied with substrate $(7-10 \mathrm{~cm}$ of industrial sand) and continuously flowing, aerated, dechlorinated tap water. Larvae were maintained at seasonal water temperatures and fed a suspension of baker's yeast once weekly ( $1 \mathrm{~g}$ of yeast per animal).

Prior to the onset of each experiment, larval sea lampreys were anaesthetized in a $0.05 \%$ solution of tricaine methanesulfonate (MS-222, Syndel Laboratories Ltd., Vancouver, British Columbia, Canada). Their lengths and weights were recorded, and groups of 10 larvae were randomly assigned by lottery to $21-1$ aquaria $(40 \times 20 \times 25$ $\mathrm{cm})$. Each aquarium was supplied with $7-10 \mathrm{~cm}$ of substrate and $10 \mathrm{l}$ of dechlorinated water. Aquaria were maintained static (i.e., not on a flowthrough system) on a $15 \mathrm{hr}$ light, $9 \mathrm{hr}$ dark light cycle and were continuously aerated. These housing conditions were similar to those previously used to study lamprey metamorphosis (Holmes and Youson, '93; Manzon and Youson, '97; Manzon et al., '98; Holmes et al., '99). Water temperature varied with the ambient room temperature (14$22^{\circ} \mathrm{C}$ ). Routine monitoring and maintenance included recording water temperatures twice daily; adding water as needed to account for evaporation; feeding larvae once weekly; cleaning aquaria, changing aquaria water and adding fresh treatments to aquaria every 2 weeks; and changing the substrate every 4 to 8 weeks. All chemicals used for experimental treatments were obtained from Sigma-Aldrich, Canada. The onset of each experiment was designated as the first day that treatments were added to the appropriate aquaria and the experiment was terminated when the last sea lamprey was sampled. Treatments were added to aquaria from stock solutions prepared in dechlorinated water unless otherwise indicated. Sampling of sea lampreys was carried out as follows: anaesthetizing in 0.05\% MS-222; recording animal lengths and weights; assigning a stage of metamorphosis ( 1 to 7 ) based on external morphology (Youson and Potter, '79); and collecting serum. Animals that died during the experiment were promptly removed and replaced with larvae marked by latex dye injection into the caudal sinus. Marked larvae were used to maintain animal density within an aquarium but were excluded from all experimental and data analyses.

\section{Experiment 1: Propylthiouracil and triiodothyronine}

Larval sea lampreys 65-95 and 105-119 $\mathrm{mm}$ in length were collected from Fish Creek, NY (September 1993) and Pigeon River, MI (June 1993), respectively. Thirty larvae from each size group (10 larvae per aquarium and three replicate tanks per experimental group) were randomly assigned to each of the following experimental groups: control (untreated), PTU (6-n-propyl-2-thiouracil), $\mathrm{T}_{3}$, and PTU plus $\mathrm{T}_{3}\left(\mathrm{PTU}+\mathrm{T}_{3}\right)$; see Table 1 for nominal ambient aquarium concentrations. In addition, at the onset of the experiment we sampled 30 larvae $65-95 \mathrm{~mm}$ in length (Fish Creek) and 20 larvae $105-119 \mathrm{~mm}$ in length (10 larvae from each stream population) to serve as baseline estimates of larval size and TH status and as a control between the two populations. We chose a PTU treatment concentration of $0.059 \mathrm{mM}(10 \mathrm{mg} / \mathrm{l})$ because this concentration was previously shown to lower serum TH concentrations by $75-95 \%$ in G. australis (Leatherland et al., '90). The experiment began in January 1994 with the addition of the aforementioned treatments to the appropriate aquaria (Table 1). Treatments were administered to each aquarium as $50 \mathrm{ml}$ of a stock solution prepared in $0.1 \mathrm{M}$ sodium hydroxide $(\mathrm{NaOH})$. Sodium hydroxide was used to increase the solubility of PTU and $\mathrm{T}_{3}$ when making the stock solutions. Sodium hydroxide did not have any effects on animal size, TH status, or the incidence of metamorphosis in an experiment conducted on larval sea lampreys from Fish Creek (Manzon and Youson, '97), so a $\mathrm{NaOH}$ control treatment was omitted in this study. All experimental animals were sampled 23 weeks after the experiment began.

\section{Experiment 2: Propylthiouracil}

Larval sea lampreys were collected from Beaverdam Brook, NY, in May 1995. Lampreys were housed at various water temperatures and animal densities throughout the spring and summer months to assess the effects these variables have on the incidence of spontaneous metamorphosis. In November 1995 we pooled the larvae from this population that were greater than $129 \mathrm{~mm}$ in length. Larvae from this pool were randomly assigned to glass aquaria (10 larvae per aquarium), and three replicate aquaria were randomly assigned to each of the control (untreated), $\mathrm{NaOH}$, and PTU experimental groups (Table 1). Treatments were administered following the procedures used in Experiment 1. The study began in No- 
TABLE 1. Baseline and experimental groups in four separate experiments, the nominal ambient aquarium concentration of the various experimental treatments, and mean sea lamprey (P. marinus) size at the time of sampling ${ }^{1}$

\begin{tabular}{|c|c|c|c|c|c|c|c|}
\hline \multirow{2}{*}{$\begin{array}{l}\text { Experiment } \\
\text { number }\end{array}$} & \multirow{2}{*}{$\begin{array}{l}\text { Size } \\
\text { group }\end{array}$} & \multirow[b]{2}{*}{ Group } & \multirow[b]{2}{*}{$N$} & \multirow[b]{2}{*}{ DS } & \multicolumn{2}{|c|}{ Mean animal size at sampling ${ }^{2}$} & \multirow[b]{2}{*}{ Treatment concentration } \\
\hline & & & & & Length $\pm 2 \mathrm{SE}$ & Weight $\pm 2 \mathrm{SE}$ & \\
\hline \multirow[t]{10}{*}{1} & \multirow[t]{5}{*}{$(65-95 \mathrm{~mm})$} & Baseline & 30 & 0 & $93.1 \pm 1.0^{\mathrm{a}}$ & $1.12 \pm 0.05^{\mathrm{a}}$ & - \\
\hline & & Control & 30 & 0 & $80.3 \pm 2.4^{\mathrm{b}}$ & $0.72 \pm 0.03^{b}$ & - \\
\hline & & PTU & 30 & 0 & $76.2 \pm 3.3^{\mathrm{b}}$ & $0.55 \pm 0.08^{\mathrm{c}}$ & $0.059 \mathrm{mM}(10 \mathrm{mg} / \mathrm{l})$ \\
\hline & & $\mathrm{PTU}+\mathrm{T}_{3}$ & 30 & 15 & $77.8 \pm 3.2^{\mathrm{b}}$ & $0.60 \pm 0.06^{\mathrm{b}}$ & $0.059 \mathrm{mM}+1.5 \times 10^{-3} \mathrm{mM}$ \\
\hline & & $\mathrm{T}_{3}$ & 30 & 0 & $78.4 \pm 2.6^{\mathrm{b}}$ & $0.65 \pm 0.06^{\mathrm{b}}$ & $1.5 \times 10^{-3} \mathrm{mM}(1 \mathrm{mg} / \mathrm{l})$ \\
\hline & \multirow[t]{5}{*}{$(105-119 \mathrm{~mm})$} & Baseline & 20 & 0 & $113.6 \pm 2.5^{\mathrm{a}}$ & $2.20 \pm 0.17^{\mathrm{a}}$ & - \\
\hline & & Control & 30 & 1 & $106.9 \pm 2.3^{b}$ & $1.68 \pm 0.13^{\mathrm{b}}$ & - \\
\hline & & PTU & 30 & 1 & $104.5 \pm 2.2^{\mathrm{b}}$ & $1.52 \pm 0.12^{\mathrm{b}}$ & $0.059 \mathrm{mM}$ \\
\hline & & $\mathrm{PTU}+\mathrm{T}_{3}$ & 30 & 1 & $104.7 \pm 2.0^{\mathrm{b}}$ & $1.60 \pm 0.12^{\mathrm{b}}$ & $0.059 \mathrm{mM}+1.5 \times 10^{-3} \mathrm{mM}$ \\
\hline & & $\mathrm{T}_{3}$ & 30 & 0 & $108.2 \pm 3.0^{\mathrm{ab}}$ & $1.76 \pm 0.16^{\mathrm{b}}$ & $1.5 \times 10^{-3} \mathrm{mM}$ \\
\hline \multirow[t]{3}{*}{2} & \multirow[t]{3}{*}{$(>129 \mathrm{~mm})$} & Control & 30 & 0 & $128.1 \pm 2.0^{\mathrm{a}}$ & $2.81 \pm 0.12^{\mathrm{a}}$ & - \\
\hline & & $\mathrm{NaOH}$ & 30 & 0 & $125.3 \pm 2.0^{\mathrm{a}}$ & $2.72 \pm 0.17^{\mathrm{a}}$ & $0.5 \mathrm{mM}$ \\
\hline & & PTU & 30 & 0 & $124.8 \pm 2.0^{\mathrm{a}}$ & $2.57 \pm 0.14^{\mathrm{a}}$ & $0.059 \mathrm{mM}$ \\
\hline \multirow[t]{8}{*}{3} & \multirow[t]{8}{*}{$(\geq 115 \mathrm{~mm})$} & Baseline & 30 & 0 & $127.0 \pm 4.2^{\mathrm{a}}$ & $2.70 \pm 0.28^{\mathrm{a}}$ & - \\
\hline & & Control & 30 & 0 & $122.4 \pm 3.8^{\mathrm{ab}}$ & $2.69 \pm 0.32^{\mathrm{a}}$ & - \\
\hline & & ${\mathrm{L}-\mathrm{KClO}_{4}}_{4}$ & 30 & 0 & $122.0 \pm 4.6^{\mathrm{ab}}$ & $2.34 \pm 0.26^{\mathrm{ab}}$ & $0.072 \mathrm{mM}(0.001 \%)$ \\
\hline & & $\mathrm{H}-\mathrm{KClO}_{4}$ & 30 & 0 & $117.1 \pm 3.5^{\mathrm{b}}$ & $1.99 \pm 0.24^{\mathrm{b}}$ & $0.72 \mathrm{mM}(0.01 \%)$ \\
\hline & & L-KSCN & 30 & 0 & $123.5 \pm 4.8^{\mathrm{ab}}$ & $2.48 \pm 0.35^{\mathrm{ab}}$ & $0.051 \mathrm{mM}(0.0005 \%)$ \\
\hline & & $\mathrm{H}-\mathrm{KSCN}$ & 30 & 0 & $123.1 \pm 5.2^{\mathrm{ab}}$ & $2.38 \pm 0.32^{\mathrm{ab}}$ & $0.51 \mathrm{mM}(0.005 \%)$ \\
\hline & & L-MMI & 30 & 18 & $120.7 \pm 5.5^{\mathrm{ab}}$ & $2.59 \pm 0.44^{\mathrm{ab}}$ & $0.087 \mathrm{mM}(0.001 \%)$ \\
\hline & & H-MMI & 30 & 17 & $122.4 \pm 6.0^{\mathrm{ab}}$ & $2.56 \pm 0.46^{\mathrm{ab}}$ & $0.87 \mathrm{mM}(0.01 \%)$ \\
\hline \multirow[t]{12}{*}{4} & \multirow[t]{6}{*}{$(110-119 \mathrm{~mm})$} & Baseline & 9 & 0 & $111.6 \pm 2.9^{\mathrm{a}}$ & $1.81 \pm 0.16^{\mathrm{a}}$ & - \\
\hline & & Control & 9 & 0 & $110.4 \pm 2.9^{\mathrm{a}}$ & $1.73 \pm 0.24^{\mathrm{ab}}$ & - \\
\hline & & $\mathrm{KClO}_{4}$ & 9 & 0 & $104.2 \pm 3.7^{\mathrm{bc}}$ & $1.42 \pm 0.16^{\mathrm{bc}}$ & $3.6 \mathrm{mM}(0.05 \%)$ \\
\hline & & $\mathrm{NaClO}_{4}$ & 9 & 0 & $101.3 \pm 2.3^{\mathrm{b}}$ & $1.33 \pm 0.16^{\mathrm{c}}$ & $3.6 \mathrm{mM}$ \\
\hline & & $\mathrm{L}-\mathrm{KCl}$ & 9 & 0 & $108.0 \pm 3.3^{\mathrm{ac}}$ & $1.67 \pm 0.16^{\mathrm{abc}}$ & $3.6 \mathrm{mM}$ \\
\hline & & $\mathrm{H}-\mathrm{KCl}$ & 9 & 9 & - & - & $18 \mathrm{mM}$ \\
\hline & \multirow[t]{6}{*}{$(>119 \mathrm{~mm})$} & Baseline & 9 & 0 & $122.9 \pm 4.1^{\mathrm{a}}$ & $2.49 \pm 0.34^{\mathrm{a}}$ & - \\
\hline & & Control & 9 & 0 & $119.9 \pm 6.1^{\mathrm{a}}$ & $2.46 \pm 0.48^{\mathrm{a}}$ & - \\
\hline & & $\mathrm{KClO}_{4}$ & 9 & 0 & $121.2 \pm 5.9^{\mathrm{a}}$ & $2.55 \pm 0.39^{\mathrm{a}}$ & $3.6 \mathrm{mM}(0.05 \%)$ \\
\hline & & $\mathrm{NaClO}_{4}$ & 9 & 0 & $118.6 \pm 5.6^{\mathrm{a}}$ & $2.36 \pm 0.39^{\mathrm{a}}$ & $3.6 \mathrm{mM}$ \\
\hline & & $\mathrm{L}-\mathrm{KCl}$ & 9 & 0 & $117.6 \pm 3.6^{\mathrm{a}}$ & $2.26 \pm 0.21^{\mathrm{a}}$ & $3.6 \mathrm{mM}$ \\
\hline & & $\mathrm{H}-\mathrm{KCl}$ & 9 & 9 & - & - & $18 \mathrm{mM}$ \\
\hline
\end{tabular}

${ }^{1}$ Abbreviations: $N$, sample size at onset; DS, number of deaths at sampling; SE, standard error; PTU, propylthiouracil; $\mathrm{T}_{3}$, triiodothyronine; $\mathrm{NaOH}$, sodium hydroxide; L, low; $\mathrm{H}$, high; $\mathrm{KClO}_{4}$, potassium perchlorate; KSCN, potassium thiocyanate; MMI, methimazole; NaClO dium perchlorate, $\mathrm{KCl}$, potassium chloride.

${ }^{2}$ Animal sizes between groups within a size group are statistically different $(P>0.05)$ if labeled with different letters.

vember 1995 and was terminated following 18 weeks of treatment, at which time all animals were sampled.

\section{Experiment 3: Potassium perchlorate, potassium thiocyanate, and methimazole}

Larval sea lampreys were collected from the Platte River, MI (August 1996). Larvae $\geq 115 \mathrm{~mm}$ in length were randomly sorted into glass aquaria (10 larvae per aquarium), and three replicate aquaria were randomly assigned to each of the following experimental groups: control (untreated); low- $\mathrm{KClO}_{4}\left(\mathrm{~L}-\mathrm{KClO}_{4}\right)$; high- $\mathrm{KClO}_{4}\left(\mathrm{H}-\mathrm{KClO}_{4}\right)$; lowKSCN (L-KSCN); high-KSCN (H-KSCN); lowMMI (2-mercapto-1-methylimidazole, L-MMI); and high-MMI (H-MMI) (Table 1). In addition, 30 larval sea lampreys were sampled at the onset of the experiment to serve as baseline data for lamprey size and TH status. The experiment began in January 1997 and was terminated 16 weeks later. However, due to the high mortality in both MMI treatment groups, all surviving MMI-treated animals were sampled 6 weeks after the study began. Sea lampreys in one randomly chosen tank 
from the control, $\mathrm{H}-\mathrm{KClO}_{4}$, and $\mathrm{H}-\mathrm{KSCN}$ experimental groups were assessed for any signs of metamorphosis at the time that the MMI-treated lampreys were sampled.

\section{Experiment 4: Potassium perchlorate, sodium perchlorate, and potassium chloride}

Larval sea lampreys were collected from Fish Creek, NY (May 1998) and sorted into two size groups, $110-119 \mathrm{~mm}$ and $>119 \mathrm{~mm}$ in length. Larvae from each size group were randomly sorted into glass aquaria (9 larvae per aquarium). One aquarium from each size group was randomly assigned to each of the following experimental groups: control (untreated); $\mathrm{KClO}_{4} ; \mathrm{NaClO}_{4}$; low potassium chloride (L-KCl); and high potassium chloride $(\mathrm{H}-\mathrm{KCl})$ (Table 1). The experiment began in March 1999 and was terminated following 13 weeks of treatment, at which time all surviving sea lampreys were sampled. At the start of the experiment we sampled 9 larvae from each size group to serve as baseline values for animal size and $\mathrm{TH}$ status.

\section{Serum collection and TH measurement}

Blood was collected from anaesthetized sea lampreys by caudal severance using heparinized haematocrit tubes and was allowed to clot overnight at $4^{\circ} \mathrm{C}$. The following morning the blood was centrifuged at 7,000g for 3-5 min, and sera were collected and stored at $-70^{\circ} \mathrm{C}$ until analyzed. Animals were sacrificed by decapitation immediately after blood collection.

Total serum $\mathrm{T}_{4}$ and $\mathrm{T}_{3}$ concentrations were determined in duplicate using the Amersham Amerlex TT4 and TT3 radioimmunoassay (RIA) kits, respectively (Johnson and Johnson, Markham, Ontario, Canada). The RIA kits were used according to Leatherland et al. ('90) to accommodate for low serum volumes. Intra- and inter-assay coefficients of variance for both TH RIAs were less than 9\% and 14\%, respectively. Assay sensitivities ranged from 7 to $11 \mathrm{nmol} / \mathrm{l}$ for $\mathrm{T}_{4}$ and from 0.15 to $0.4 \mathrm{nmol} / /$ for $\mathrm{T}_{3}$. Serum $\mathrm{T}_{4}$ and $\mathrm{T}_{3}$ concentrations were determined for Experiments 1, 3, and 4 but not for Experiment 2 (serum samples were lost when our freezer failed). In some instances, equal volumes of serum from two or more sea lampreys from the same experimental aquarium were pooled to produce a single sample of sufficient volume to assay both TH.

\section{Statistical analyses}

The data from all four experiments were analyzed with analysis of variance (ANOVA) and
Tukey-Kramer's post-hoc test using individual aquaria and/or experimental groups as independent variables and animal length, weight, and serum TH concentrations as dependent variables. Prior to these statistical analyses, all data were tested for homoscedasticity with Cochran's $Q$ test; data that did not meet this assumption were transformed $\left(\log _{10}\right)$ to minimize the heterogeneity of the variances (Sokal and Rohlf, '80). All statistical analyses were performed using Statistix for DOS. The data are presented as mean $\pm 2 \mathrm{SE}$ (standard errors), and differences were accepted as statistically significant if $P<0.05$. Any deviations from these statistical analyses are indicated as they are presented in the Results section.

\section{RESULTS}

\section{Experiment 1: Propylthiouracil and triiodothyronine}

Aquaria water temperatures ranged from 14 to $18^{\circ} \mathrm{C}$ with a mean of $16 \pm 0.1^{\circ} \mathrm{C}$. In the PTU+T experimental group (65-95 mm size group) we observed a $50 \%$ mortality rate; however, $67 \%$ of these deaths occurred in a single aquarium in which all larvae died (Table 1). Metamorphosis was not observed in any of the treated larval sea lampreys, but one control animal was at stage 3 of metamorphosis at the time of sampling.

At the start of the experiment, larval length and weight in the 65-95 mm size group did not differ between the four experimental groups; the overall mean size of these larvae was $84.4 \pm 1.4 \mathrm{~mm}$ and $0.89 \pm 0.04 \mathrm{~g}$. However, baseline larvae in this size group had a mean length and weight of 93.1 $\pm 1 \mathrm{~mm}$ and $1.12 \pm 0.05 \mathrm{~g}$, respectively, which were significantly greater than those recorded for each of the experimental groups. Significant differences in size between larvae of the four experimental groups and/or the baseline group were not observed in the 105-119 mm size group at the onset of the experiment; the overall mean size of these larvae was $113.3 \pm 0.7 \mathrm{~mm}$ and $2.20 \pm 0.05$ $\mathrm{g}$. At the end of the experiment, larvae within a size group tended to be smaller in size than at the onset and experimental larvae were significantly smaller than baseline larvae, indicating a decrease in animal size over the course of the experiment (Table 1).

At the end of the experiment, 65-95 mm larvae in the control, PTU, PTU+ $\mathrm{T}_{3}$, and $\mathrm{T}_{3}$ experimental groups had serum $\mathrm{T}_{4}$ concentrations $(40 \pm 6.2,35$ $\pm 6.6,48 \pm 11.2$, and $113 \pm 19.7 \mathrm{nmol} / \mathrm{l}$, respectively) that were significantly lower than values measured 
65 - $95 \mathrm{~mm}$ size group


Fig. 1. Mean ( \pm 2 standard errors) serum thyroxine $\left(\mathrm{T}_{4}\right.$; $\mathbf{A}$ and $\mathbf{C})$ and triiodothyronine $\left(\mathrm{T}_{3} ; \mathbf{B}\right.$ and $\left.\mathbf{D}\right)$ concentrations in sea lampreys of two different groups (based on length). Lampreys were either untreated as in the baseline and control groups or treated with propylthiouracil (PTU), PTU and $\mathrm{T}_{3}\left(\mathrm{PTU}+\mathrm{T}_{3}\right)$, or $\mathrm{T}_{3}$ for 23 weeks. Baseline groups were

in baseline larvae at the start of the experiment (154 $\pm 14.5 \mathrm{nmol} / \mathrm{l})$ (Fig. 1A). Treatment of 65-95 $\mathrm{mm}$ larvae with exogenous $\mathrm{T}_{3}$ significantly elevated serum $\mathrm{T}_{4}$ concentrations relative to values in the control, PTU, and PTU $+\mathrm{T}_{3}$ experimental groups (Fig. 1A).

In the 105-119 mm size group, serum $\mathrm{T}_{4}$ concentrations in baseline larvae $(145 \pm 44.4 \mathrm{nmol} / \mathrm{l})$ were significantly greater than values in the control and PTU-treated animals $(40 \pm 4.9$ and $41 \pm$ $4.4 \mathrm{nmol} / 1$, respectively) but did not differ from values in the $\mathrm{T}_{3}$ - or PTU+T $\mathrm{T}_{3}$-treated (192 \pm 26 and $120 \pm 26.7 \mathrm{nmol} / \mathrm{l}$, respectively) animals (Fig. 1C). Exogenous $\mathrm{T}_{3}$ treatment, in the presence or absence of PTU, significantly elevated serum $\mathrm{T}_{4}$ concentrations relative to values in the control and PTU experimental groups (Fig. 1C). PTU did not alter serum $\mathrm{T}_{4}$ concentrations relative to control values in either size group (Fig. 1A,C). Serum $\mathrm{T}_{3}$ concentrations of animals in either size group did not differ significantly between any of the experimental groups (i.e., control, $\mathrm{PTU}, \mathrm{PTU}+\mathrm{T}_{3}$, or $\mathrm{T}_{3}$ ), but within each size group the serum $\mathrm{T}_{3}$ concen-
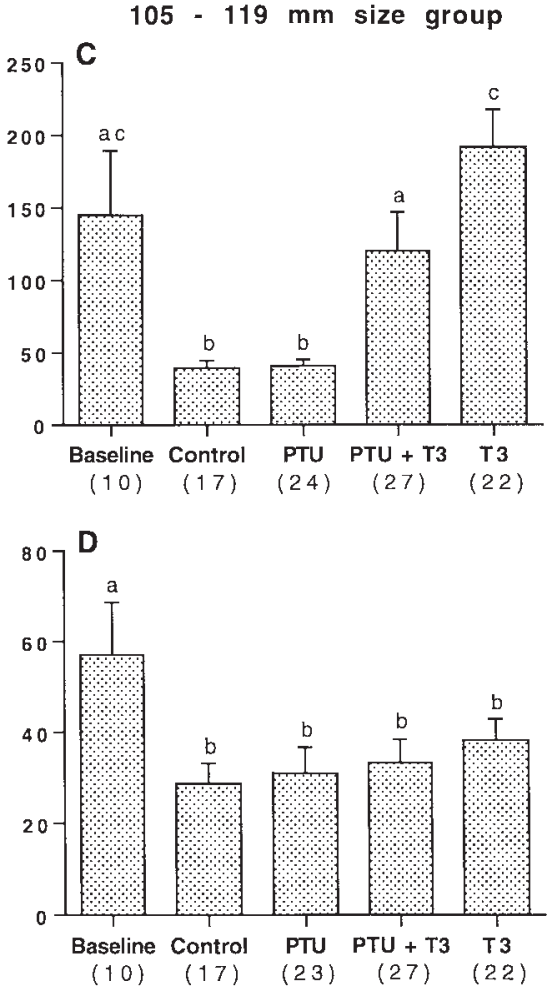

sampled at the start of the experiment, but control groups were sampled at the same time as treated lampreys. Serum $\mathrm{T}_{4}$ and $\mathrm{T}_{3}$ concentrations are significantly different $(P<0.05)$ if labeled with different letters. Sample size for each group is indicated in parentheses below the abscissa.

trations of baseline animals were significantly greater than those of the experimental groups (Fig. 1B,D).

\section{Experiment 2: Propylthiouracil}

Aquaria water temperatures ranged from 15 to $21^{\circ} \mathrm{C}$ with a mean value of $17 \pm 0.1^{\circ} \mathrm{C}$. At the start of the experiment, significant differences in sea lamprey length or weight were not observed between the various experimental groups; the overall mean animal size was $133 \pm 0.9 \mathrm{~mm}$ and 3.42 $\pm 0.08 \mathrm{~g}$. As was the case for Experiment 1, larvae tended to be smaller at the time of sampling than at the start of the experiment (Table 1). Metamorphosis was not observed, and no deaths occurred in any experimental groups.

\section{Experiment 3: Potassium perchlorate, potassium thiocyanate, and methimazole}

Aquarium water temperature ranged from 18 to $22^{\circ} \mathrm{C}$ with a mean of $20 \pm 0.1^{\circ} \mathrm{C}$. Mortalities were not observed in the control, $\mathrm{KClO}_{4}$, or KSCN experimental groups; however, a high incidence 
of mortality in the L-MMI and H-MMI treatment groups precipitated the sampling of all surviving sea lampreys from these groups 6 weeks after the experiment started (Table 1). At this time 18/30 and 17/30 larvae had died in the L-MMI and $\mathrm{H}$ MMI experimental groups, respectively. All comparisons between experimental groups at the time of sampling were made using MMI larvae sampled 6 weeks after the experiment began and control, $\mathrm{KClO}_{4}$, and $\mathrm{KSCN}$ larvae sampled 10 weeks later, unless otherwise indicated.

Significant differences in mean larval length or weight were not observed between the seven experimental groups and/or baseline larvae at the start of the experiment; the overall mean size was $130.3 \pm 1.6 \mathrm{~mm}$ and $3.23 \pm 0.1 \mathrm{~g}$. The mean size of all experimental animals at the time of sampling was $121.6 \pm 1.8 \mathrm{~mm}$ and $2.40 \pm 0.12 \mathrm{~g}$ (Table 1 ), indicating that animal size had decreased over the course of the experiment.

The three goitrogen treatments used in this experiment induced precocious metamorphosis in sea lampreys; however, the number of metamorphosing lampreys varied depending on the type and concentration of goitrogen used. Treatment of larval sea lampreys with L-MMI or H-MMI for 6 weeks induced metamorphosis in $33 \%$ and $46 \%$ of surviving sea lampreys, respectively (Fig. 2A; Table 1). When the MMI-treated sea lampreys were sampled, we also examined 10 larvae from the control, $\mathrm{H}-\mathrm{KClO}_{4}$, and $\mathrm{H}-\mathrm{KSCN}$ experimental groups and found that only 2 sea lampreys from the $\mathrm{H}-\mathrm{KClO}_{4}$ treatment group had commenced metamorphosis (Fig. 2A).

After 16 weeks of treatment, metamorphosis was not observed in the control group, but $10 \%$, $66 \%, 20 \%$, and $43 \%$ of lampreys had begun to metamorphose in the $\mathrm{L}_{-} \mathrm{KClO}_{4}, \mathrm{H}-\mathrm{KClO}_{4}, \mathrm{~L}-\mathrm{KSCN}$, and H-KSCN experimental groups, respectively (Fig. 2B). We observed sea lampreys in each of the seven stages of metamorphosis (Fig. 2B), and these goitrogen-treated lampreys were clearly undergoing external morphological changes reminiscent of spontaneous metamorphosis. However, in most instances the timing of these morphological changes was asynchronous compared to what is observed during spontaneous metamorphosis, and goitrogen-induced metamorphosis did not proceed to completion.

To determine the effects of the various treatments on serum TH concentrations, we tested for statistically significant differences between experimental groups and/or baseline animals (Fig. 3). In addition, we tested for differences in serum $\mathrm{TH}$

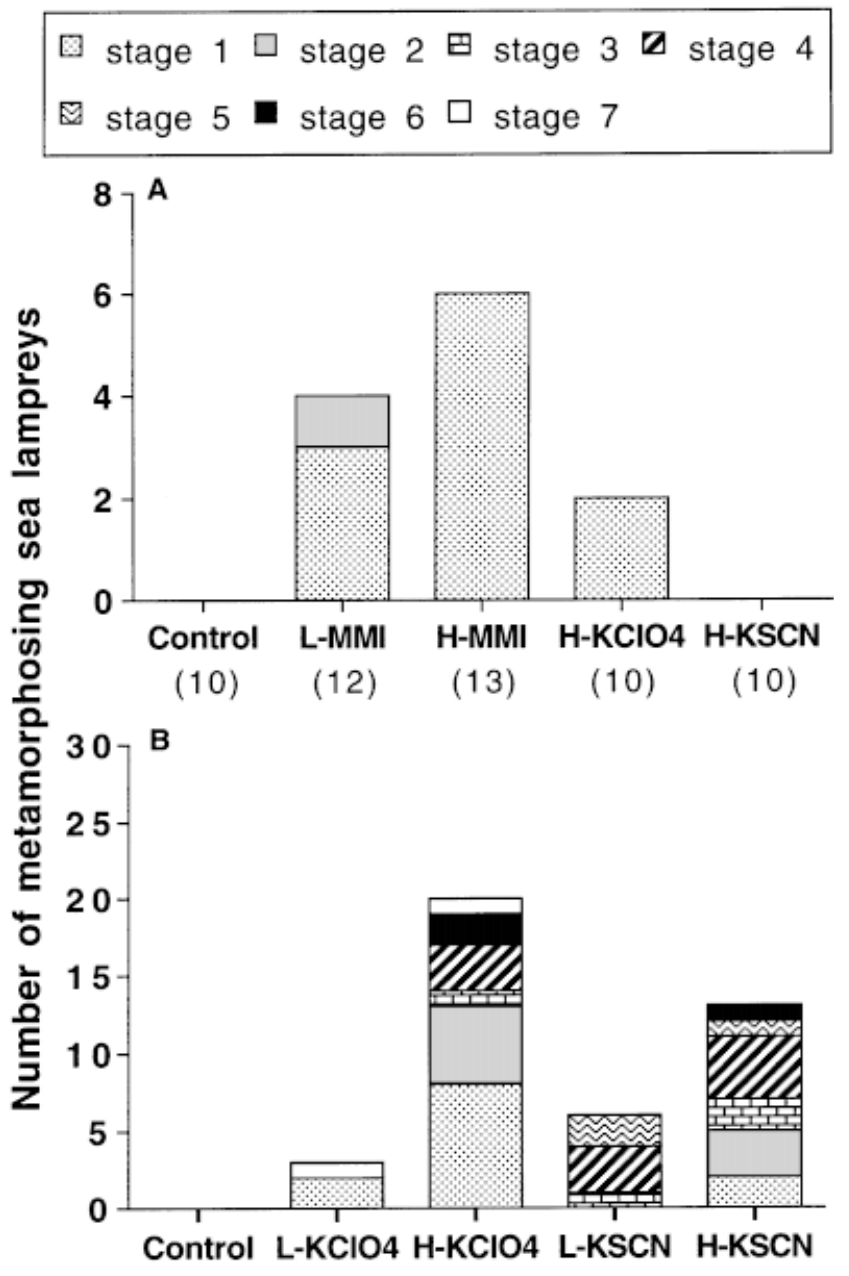

Fig. 2. Stage and total number of metamorphosing sea lampreys in untreated (control) and goitrogen-treated individuals following 6 weeks $(\mathbf{A})$ or 16 weeks $(\mathbf{B})$. Goitrogen treatments included: methimazole (MMI), potassium perchlorate $\left(\mathrm{KClO}_{4}\right)$, and potassium thiocyanate (KSCN); each goitrogen was administered at a high $(\mathrm{H})$ and low $(\mathrm{L})$ concentration (see Table 1). Sample size is equal to 30 unless otherwise indicated in parentheses below the abscissa.

concentrations between larval and metamorphosing lampreys within an experimental group (Table 2). Serum $\mathrm{T}_{4}$ concentrations in baseline sea lampreys were significantly greater than concentrations in sea lampreys from the seven experimental groups (Fig. 3A). Sea lampreys in the H-KSCN, L$\mathrm{KClO}_{4}, \mathrm{H}-\mathrm{KClO}_{4}$, L-MMI, and H-MMI experimental groups had serum $\mathrm{T}_{4}$ concentrations that were significantly lower than control values, but L-KSCN treatment did not alter serum $\mathrm{T}_{4}$ concentrations (Fig. 3A). Within the L-KSCN and H-KSCN experimental groups, the serum $\mathrm{T}_{4}$ concentrations of metamorphosing lampreys were significantly lower than values for lampreys which did not metamorphose (Table 2). 

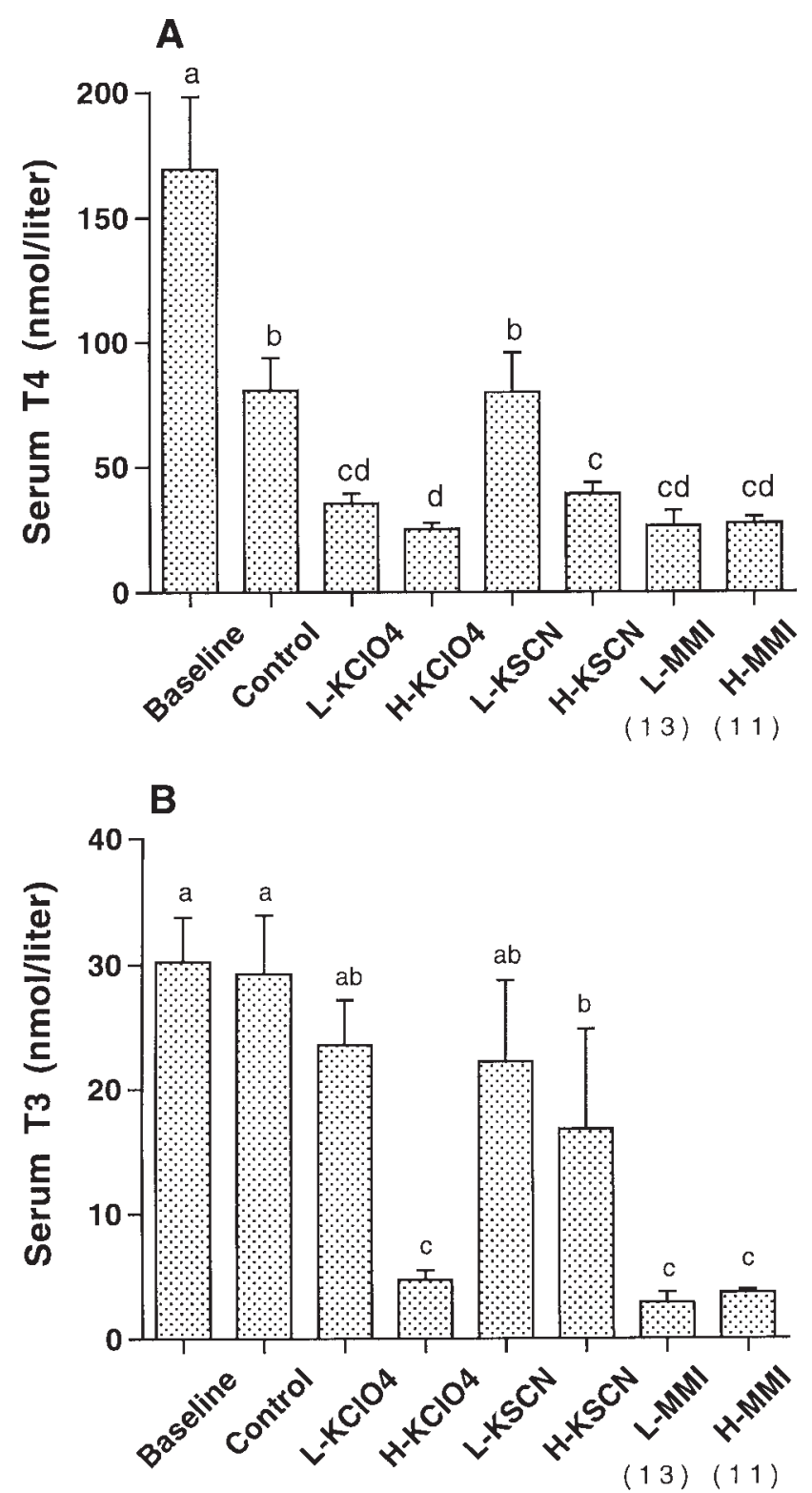

Fig. 3. Mean ( \pm 2 standard errors) serum thyroxine $\left(\mathrm{T}_{4}\right)$ and triiodothyronine $\left(\mathrm{T}_{3}\right)$ concentrations in sea lampreys. Lampreys were either untreated, as in the baseline and control groups, or treated with potassium perchlorate $\left(\mathrm{KClO}_{4}\right)$ or potassium thiocyanate (KSCN) for 16 weeks or with methimazole (MMI) for 6 weeks. Goitrogen treatment concentrations were either high $(\mathrm{H})$ or low $(\mathrm{L})$ as indicated on the abscissa (see Table 1). Baseline groups were sampled at the start of the experiment but control groups were sampled at the termination of the experiment ( 16 weeks). Sample size is equal to 30 unless otherwise indicated in parentheses below the abscissa. Concentrations labeled with different letters are significantly different $(P<0.05)$.

Serum $\mathrm{T}_{3}$ concentrations in the H-KSCN, H$\mathrm{KClO}_{4}$, L-MMI, and H-MMI experimental groups were significantly lower than concentrations in the control and baseline groups (Fig. 3B). However, serum $\mathrm{T}_{3}$ concentrations did not differ significantly between the baseline, control, L-KSCN, and L$\mathrm{KClO}_{4}$ lampreys (Fig. 3B). Significant differences in serum $\mathrm{T}_{3}$ concentrations between larval and metamorphosing animals within an experimental group were observed in the L-KSCN, H-KSCN, and L-MMI experimental groups (Table 2). Surprisingly, serum $\mathrm{T}_{3}$ concentrations in metamorphosing L-MMI sea lampreys were significantly greater than the values in larval L-MMI sea lampreys; in both cases serum $\mathrm{T}_{3}$ concentrations were much lower than control values (Table 2).

\section{Experiment 4: Potassium perchlorate, sodium perchlorate, and potassium chloride}

Aquaria water temperatures ranged from 17 to $22^{\circ} \mathrm{C}$ with a mean value of $19.6 \pm 0.2^{\circ} \mathrm{C}$. With the exception of the $\mathrm{H}-\mathrm{KCl}$ experimental groups, in which all animals died within 4 days of the start of the experiment, no deaths occurred in either size group (Table 1). There were no differences in larval size between experimental and/or baseline groups within either size group at the onset of the experiment. The mean animal size at this time was 127.7 $\pm 2.1 \mathrm{~mm}$ and $2.77 \pm 0.18 \mathrm{~g}$ in the $>119 \mathrm{~mm}$ size group and $113.1 \pm 0.1 \mathrm{~mm}$ and $1.89 \pm 0.06 \mathrm{~g}$ in the 110-119 mm size group. Larvae of both size groups were smaller in size at the time they were sampled than at the start of the experiment (Table 1).

Metamorphosis was not observed in control or L-KCl-treated lampreys of either size group. However, in the $110-119 \mathrm{~mm}$ size group, $33 \%$ of $\mathrm{NaClO}_{4}$ - and $\mathrm{KClO}_{4}$-treated sea lampreys were in either stage 1 or 2 of metamorphosis. The incidence of metamorphosis in lampreys $>119 \mathrm{~mm}$ in length following $\mathrm{KClO}_{4}$ or $\mathrm{NaClO}_{4}$ treatment was $89 \%$, and these animals were in stages $1,2,3$, and 4 of metamorphosis (Fig. 4).

In general, serum TH concentrations in baseline animals were significantly greater than those of experimental lampreys; serum $\mathrm{T}_{3}$ in $\mathrm{L}-\mathrm{KCl}$ sea lampreys (>119 $\mathrm{mm}$ size group) was the only exception to this trend (Fig. 5). Serum $\mathrm{T}_{4}$ and $\mathrm{T}_{3}$ concentrations did not differ significantly between control and L-KCl sea lampreys within a size group (Fig. 5). The goitrogens $\mathrm{KClO}_{4}$ and $\mathrm{NaClO}_{4}$ significantly lowered serum $\mathrm{TH}$ concentrations in lampreys from both size groups relative to values in the baseline, control, and L-KCl groups (Fig. 5).

\section{DISCUSSION}

Over the past four decades several laboratories have studied the effects of goitrogens on lamprey physiology and metamorphosis but the results have 
$T A B L E$ 2. Comparison of mean serum thyroxine and triiodothyronine concentrations in larval (A) and metamorphosing (M) sea lampreys (P. marinus) following various goitrogen treatments (Experiment 3$)^{1,2}$

\begin{tabular}{|c|c|c|c|c|c|c|}
\hline \multirow[b]{2}{*}{ Group } & \multicolumn{3}{|c|}{ Thyroxine (nmol/1) } & \multicolumn{3}{|c|}{ Triiodothyronine (nmol/l) } \\
\hline & $\mathrm{A}$ & $\mathrm{M}$ & $\mathrm{AM}$ & $\mathrm{A}$ & $\mathrm{M}$ & $\mathrm{AM}$ \\
\hline Baseline & $\begin{array}{c}169 \\
(30,28.9)\end{array}$ & - & $\begin{array}{c}169 \\
(30,28.9)\end{array}$ & $\begin{array}{c}30.21 \\
(30,3.6)\end{array}$ & - & $\begin{array}{c}30.21 \\
(30,3.6)\end{array}$ \\
\hline Control & $\begin{array}{c}80.7 \\
(29,12.9)\end{array}$ & - & $\begin{array}{c}80.7 \\
(29,12.9)\end{array}$ & $\begin{array}{c}29.25 \\
(30,4.7)\end{array}$ & - & $\begin{array}{c}29.25 \\
(30,4.7)\end{array}$ \\
\hline $\mathrm{L}-\mathrm{KClO}_{4}$ & $\begin{array}{c}35.2 \\
(27,4.14)\end{array}$ & $\begin{array}{c}41.8 \\
(2,12.0)\end{array}$ & $\begin{array}{c}35.6 \\
(29,3.95)\end{array}$ & $\begin{array}{c}24.32 \\
(27,3.68)\end{array}$ & $\begin{array}{c}13.36 \\
(2,7.15)\end{array}$ & $\begin{array}{c}23.56 \\
(29,3.6)\end{array}$ \\
\hline $\mathrm{H}-\mathrm{KClO}_{4}$ & $\begin{array}{c}22.9 \\
(10,4.76)\end{array}$ & $\begin{array}{c}26.5 \\
(19,3.11)\end{array}$ & $\begin{array}{c}25.2 \\
(29,2.6)\end{array}$ & $\begin{array}{c}4.75 \\
(10,1.01)\end{array}$ & $\begin{array}{c}4.70 \\
(18,1.14)\end{array}$ & $\begin{array}{c}4.72 \\
(28,0.8)\end{array}$ \\
\hline L-KSCN & $\begin{array}{c}87.7 \\
(24,16.18)\end{array}$ & $\begin{array}{c}48.0^{*} \\
(6,34.4)\end{array}$ & $\begin{array}{c}79.7 \\
(30,15.9)\end{array}$ & $\begin{array}{c}27.66 \\
(22,6.49)\end{array}$ & $\begin{array}{c}2.15^{*} \\
(6,0.84)\end{array}$ & $\begin{array}{c}22.19 \\
(28,6.5)\end{array}$ \\
\hline $\mathrm{H}-\mathrm{KSCN}$ & $\begin{array}{c}44.6 \\
(15,6.35)\end{array}$ & $\begin{array}{c}32.8^{*} \\
(13,4.50)\end{array}$ & $\begin{array}{c}39.1 \\
(28,4.53)\end{array}$ & $\begin{array}{c}31.13 \\
(14,10.69)\end{array}$ & $\begin{array}{c}1.26^{*} \\
(13,0.39)\end{array}$ & $\begin{array}{c}16.75 \\
(27,8.08)\end{array}$ \\
\hline L-MMI & $\begin{array}{c}24.8 \\
(7,10.48)\end{array}$ & $\begin{array}{c}29.1 \\
(5,2.07)\end{array}$ & $\begin{array}{c}26.6 \\
(12,6.1)\end{array}$ & $\begin{array}{c}2.18 \\
(7,1.03)\end{array}$ & $\begin{array}{c}3.95^{*} \\
(5,0.88)\end{array}$ & $\begin{array}{c}2.92 \\
(12,0.8)\end{array}$ \\
\hline H-MMI & $\begin{array}{c}24.7 \\
(6,2.69)\end{array}$ & $\begin{array}{c}30.1 \\
(6,3.85)\end{array}$ & $\begin{array}{c}27.41 \\
(12,2.77)\end{array}$ & $\begin{array}{c}3.79 \\
(6,0.31)\end{array}$ & $\begin{array}{c}3.58 \\
(6,0.40)\end{array}$ & $\begin{array}{c}3.68 \\
(12,0.23)\end{array}$ \\
\hline
\end{tabular}

${ }^{1}$ Abbreviations: AM, mean of combined larval and metamorphosing data; L, low; $\mathrm{H}$, high; $\mathrm{KClO}_{4}$, potassium perchlorate; KSCN, potassium thiocyanate; MMI, methimazole.

${ }^{2}$ Values in parentheses are sample size and two standard errors of the mean, respectively.

*Significantly different from larval values within a group.

been variable. The goitrogen $\mathrm{KClO}_{4}$ depresses serum TH concentrations and can initiate the process of metamorphosis in several species of lampreys (Hoheisel and Sterba, '63; Suzuki, '86; Holmes and Youson, '93; Manzon and Youson, '97, '99; Manzon et al., '98; Holmes et al., '99). Serum $\mathrm{T}_{4}$ and $\mathrm{T}_{3}$ concentrations in larval lampreys following $\mathrm{KClO}_{4}$ treatment were $18-88 \%$ and $72-95 \%$ lower than control values, respectively (Youson et al., '95; Manzon and Youson, '97; Manzon et al., '98; Holmes et al., '99). The magnitudes of these TH declines in $\mathrm{KClO}_{4}$-treated lampreys are comparable to those observed in the early stages of metamorphosis. Sea lampreys at stage 3 of spontaneous metamorphosis have serum $\mathrm{T}_{4}$ and $\mathrm{T}_{3}$ concentrations that are 40 $74 \%$ and $90 \%$ lower than premetamorphic larvae, respectively (Wright and Youson, '77; Lintlop and Youson, '83; Youson et al., '94). The findings of these metamorphosis studies are consistent with the hypothesis that a decline in serum TH concentrations may be involved in the initiation of lamprey metamorphosis. Alternatively, high serum concentrations of $\mathrm{TH}$ can inhibit or retard both the spontaneous (Youson et al., '97) and induced (Manzon and Youson, '97; Manzon et al., '98) metamorphosis of lampreys. Whether TH concentrations must decline below a threshold level or the decline from premetamorphic concentrations must be of a particular magnitude remains to be elucidated.

Studies investigating the effects of PTU on lam- prey serum TH concentrations and metamorphosis are not consistent and tend to challenge the interpretation of the results from $\mathrm{KClO}_{4}$ induction experiments. The induction of metamorphosis following PTU treatment was first reported in L. reissneri by Suzuki ('87). Subsequently, both Leatherland et al. ('90) and Holmes et al. ('99) reported a significant decline in the serum TH concentrations of $G$. australis and $L$. appendix, respectively, following treatment with PTU. Despite serum TH concentrations that were 54-95\% lower than control values, PTU treatment did not induce precocious metamorphosis in either species of lamprey. This absence of metamorphosis indicates that a decline in serum $\mathrm{TH}$ concentrations may not be sufficient to induce metamorphosis. Alternatively, PTU may have other effects on the physiology of some lamprey species that preclude the induction of metamorphosis. In this study we attempted to clarify (i) whether several goitrogens can depress serum TH concentrations and induce sea lamprey metamorphosis, (ii) whether this induction of metamorphosis is specific to $\mathrm{KClO}_{4}$, and (iii) whether PTU is unique among goitrogens in its variability at inducing metamorphosis in lampreys. The variable effects of PTU on lamprey metamorphosis may involve species differences; a possibility which cannot be fully assessed by this study.

In the current study, a total of 90 larval sea lampreys of three different sizes groups (65-95, 


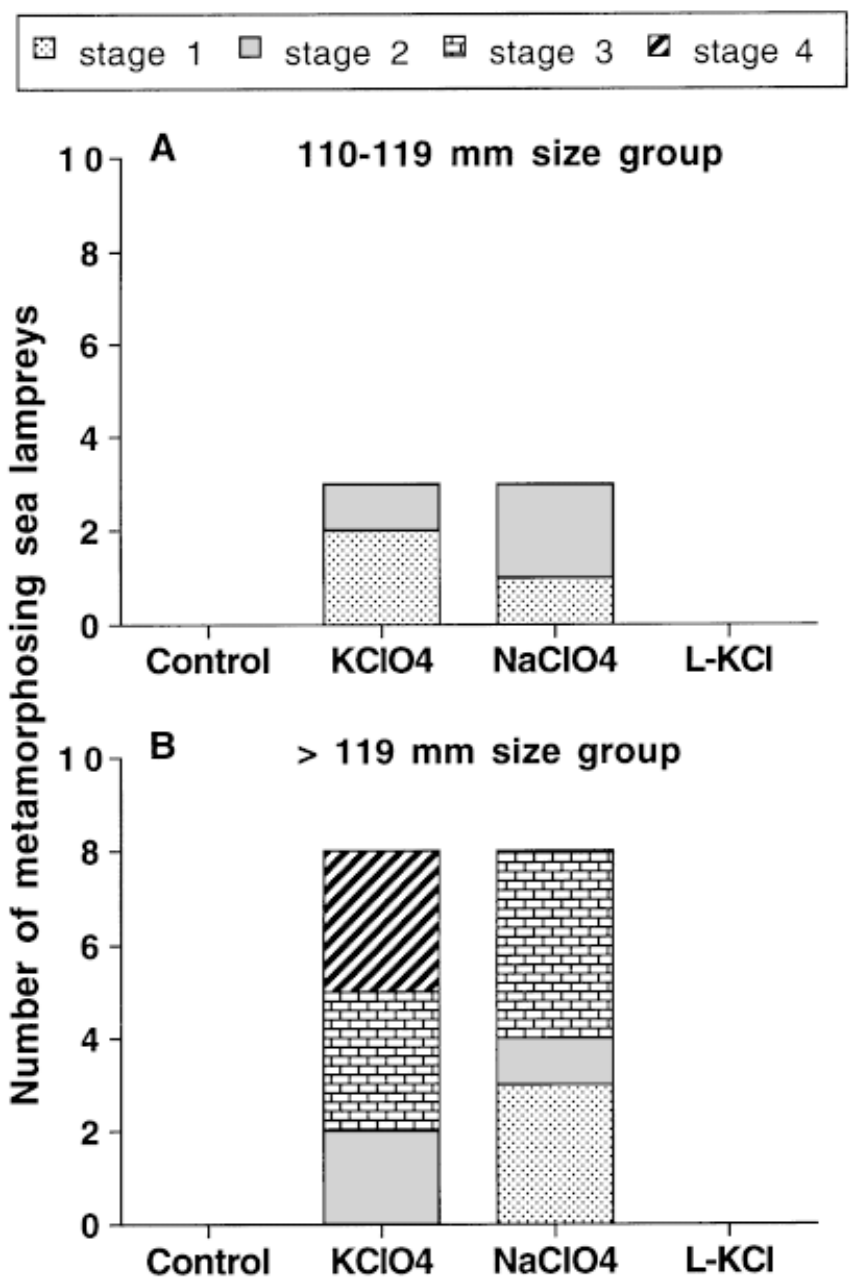

Fig. 4. Stage and total number of metamorphosing sea lampreys in untreated (control) and treated individuals from two different size groups (based on length). Treatments included two goitrogen experimental groups (potassium perchlorate $\left[\mathrm{KClO}_{4}\right]$ and sodium perchlorate $\left.\left[\mathrm{NaClO}_{4}\right]\right)$, and a low potassium chloride (L-KCl) experimental group. Sample size for each group is nine.

105-119, and $>129 \mathrm{~mm}$ in length) were exposed to the goitrogen PTU for 18-23 weeks. Consistent with the findings of Leatherland et al. ('90) and Holmes et al. ('99), but contrary to those of Suzuki ('87, '89), we did not observe any signs of metamorphosis in PTU-treated sea lampreys. Surprisingly, PTU treatment did not significantly alter serum $\mathrm{TH}$ concentrations relative to our control group (Fig. 1). Although it is tempting to suggest that the absence of metamorphosis in our experiment was due to the fact that PTU treatment did not lower serum $\mathrm{TH}$ concentrations, the studies of Leatherland et al. ('90) and Holmes et al. ('99) provide evidence which could refute this as a possibility. We cannot determine why PTU did not affect sea lamprey serum TH concentrations in Experiment 1, but this result may be related to the physiological condition of the sea lampreys in this study. Unfortunately, we were unable to determine serum $\mathrm{TH}$ concentrations in PTU-treated larvae greater than $130 \mathrm{~mm}$ in length (Experiment 2). Future studies should include dose-response curves to determine the minimum PTU treatment concentration that can depress serum TH titers in larval sea lampreys to titers similar to those measured in metamorphic sea lampreys.

A change in the physiological condition of larval sea lampreys over the course of the experiment may have contributed to the absence of a decline in serum $\mathrm{TH}$ concentrations in PTUtreated larvae. In Experiments 1 and 2 we observed a decrease in mean larval length and weight over the course of the experiment. In general, larvae within a treatment group were smaller in size at the time of sampling than they were when the study began. Although the exact cause of this decrease in size is unknown, it may be related to an inadequate food supply in captivity. TH status also changed over time; serum TH concentrations in baseline larval sea lampreys were significantly greater than the values for control larvae at the time of sampling in both size groups in Experiment 1 (Fig. 1). Similar trends towards a decrease in the mean animal size and serum $\mathrm{TH}$ concentrations over the duration of an experiment were also observed in Experiments 3 and 4 (Figs. 3 and 5). However, goitrogen treatment in each of these experiments depressed serum TH concentrations and induced metamorphosis. These results from Experiments 3 and 4 minimize the likelihood that a decrease in size or a change in $\mathrm{TH}$ status from baseline values was responsible for the absence of metamorphosis or a decline in serum $\mathrm{TH}$ concentrations in Experiments 1 and 2.

The treatment of larval sea lampreys 65-95 and $105-119 \mathrm{~mm}$ in length with exogenous $\mathrm{T}_{3}$ significantly elevated serum $\mathrm{T}_{4}$ concentrations but had no significant effect on serum $\mathrm{T}_{3}$ concentrations. These findings are similar to those observed by Manzon and Youson ('97) with sea lampreys 110$119 \mathrm{~mm}$ in length. In this earlier study, exogenous $\mathrm{T}_{3}$ significantly elevated serum $\mathrm{T}_{4}$ concentrations in six out of six sampling periods ranging from 4-24 weeks of treatment. However, serum $\mathrm{T}_{3}$ concentrations increased in only two of these six sampling periods. In a second study using larval sea lampreys $\geq 120 \mathrm{~mm}$ in length, Manzon et al. ('98) found that exogenous $\mathrm{T}_{3}$ consistently elevated both 

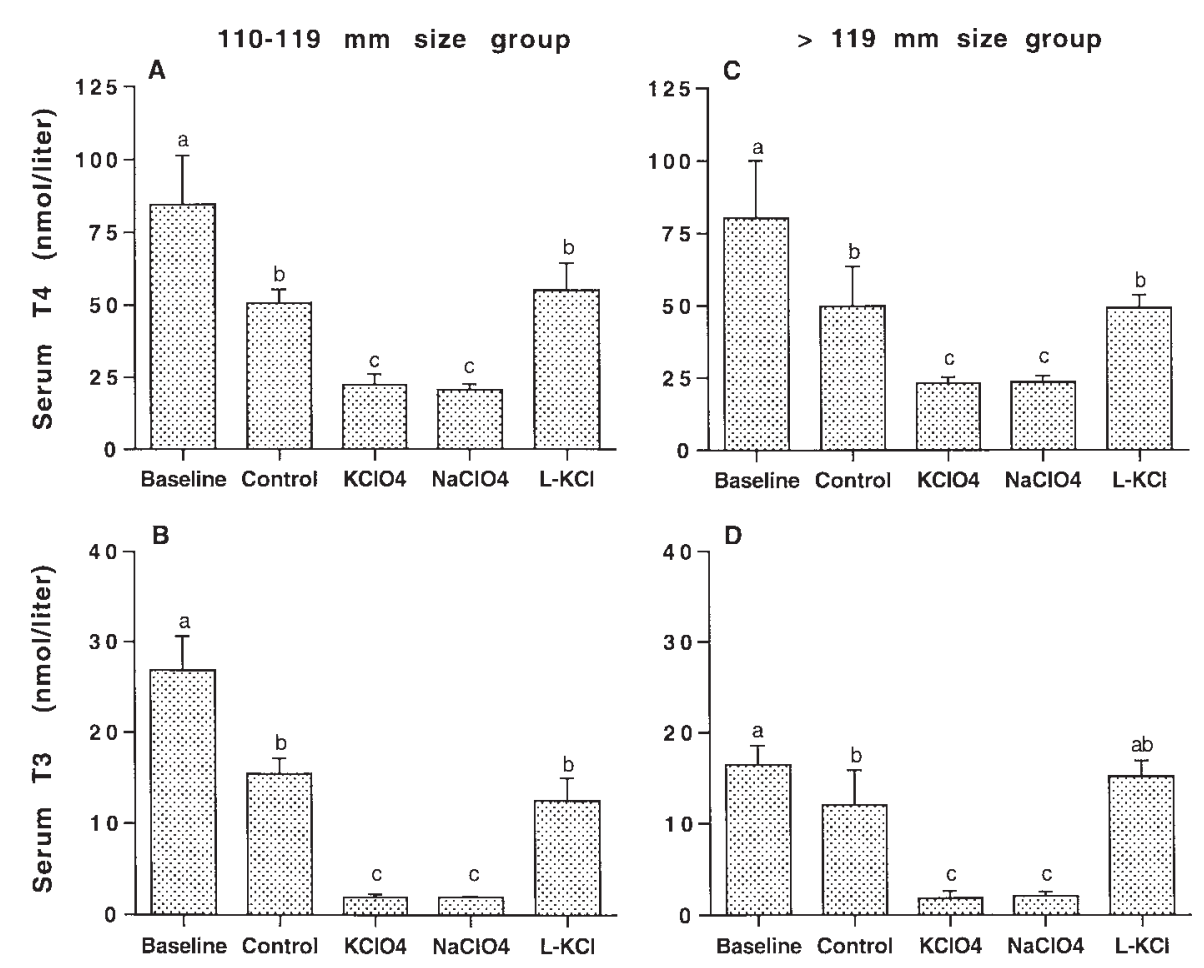

Fig. 5. Mean ( \pm 2 standard errors) serum thyroxine $\left(\mathrm{T}_{4}\right)$ and triiodothyronine $\left(\mathrm{T}_{3}\right)$ concentrations in untreated (baseline and control) and treated sea lampreys from two different size groups (based on length). Treatments included two goitrogen experimental groups (potassium perchlorate $\left[\mathrm{KClO}_{4}\right]$

serum $\mathrm{T}_{4}$ and $\mathrm{T}_{3}$ concentrations. These data imply that large larvae $(\geq 120 \mathrm{~mm}$ in length) can regulate $\mathrm{TH}$ synthesis and metabolism differently than the smaller larvae used in the present study. Eales et al. ('97, 2000) have shown that the activity of the deiodinase pathways change during and after metamorphosis. Similarly, changes in $\mathrm{TH}$ deiodinase activity and/or metabolism may occur within the larval period; serum TH concentrations increase throughout the larval period indicating the potential for a change in $\mathrm{TH}$ regulation. The ability of exogenous $\mathrm{T}_{3}$ to elevate serum $\mathrm{T}_{4}$ without increasing serum $\mathrm{T}_{3}$ is an interesting phenomenon from a regulatory standpoint. The exact regulatory mechanism responsible for elevating serum $\mathrm{T}_{4}$ concentrations is unknown but could involve changes in the regulation of $\mathrm{TH}$ synthesis, secretion, deiodination, and/or degradation.

All sea lampreys in the control, $\mathrm{KClO}_{4}$, and KSCN experimental groups survived for the duration of Experiment 3. However, a large proportion ( $>55 \%$ ) of MMI-treated larvae died early in the experiment; this led to the sampling of all surviving MMI-treated sea lampreys 6 weeks after the experiment began. The two concentrations of

and sodium perchlorate $\left[\mathrm{NaClO}_{4}\right]$ ) and a low potassium chloride (L-KCl) experimental group. Sample size for each group is nine. Concentrations are significantly different $(P<0.05)$ if labeled with different letters.

MMI used in the current study $(0.087$ and 0.87 $\mathrm{mM})$ were lower than the concentration $(1 \mathrm{mM})$ that Brown ('97) routinely uses to inhibit amphibian metamorphosis. However, he observed an unpredictable mortality rate in zebrafish at MMI concentrations greater than or equal to $0.5 \mathrm{mM}$, and $0.3 \mathrm{mM}$ was the highest MMI concentration that was not toxic. Although we do not know the cause of the lamprey mortality in the MMI treatment, it appears to be consistent with the unpredictable effects of MMI toxicity observed in zebrafish.

As was the case in all four experiments discussed in this paper, Experiment 3 was conducted at a time of year when sea lampreys do not metamorphose spontaneously. Thus it was not surprising that larval sea lampreys in the untreated control groups did not undergo metamorphosis; yet metamorphosis was observed in all goitrogen treatment groups in Experiment 3. Following a 6-week exposure, MMI was more successful at inducing precocious metamorphosis in larval sea lampreys than either $\mathrm{KClO}_{4}$ or KSCN. At 6 weeks we observed that 10/23 MMI-treated sea lampreys had commenced metamorphosis, as compared to 
2/10 $\mathrm{H}-\mathrm{KClO}_{4}$-treated and 0/10 $\mathrm{H}$-KSCN-treated sea lampreys (Fig. 2A). These data differ from those of the PTU experiments and indicate that MMI, a thyroid peroxidase inhibitor, can induce metamorphosis in larval sea lampreys. MMI may also have the potential to induce metamorphosis in larval sea lampreys more rapidly than the other goitrogens tested to date. However, a cautious interpretation of these data is necessary since only one third of the $\mathrm{H}-\mathrm{KClO}_{4}$ - and $\mathrm{H}-\mathrm{KSCN}$-treated sea lampreys were examined at this 6 -week point, metamorphosing sea lampreys in the MMI experimental groups were in the early stages of metamorphosis, and MMI treatment was toxic to many individuals. Perhaps the rapid induction of metamorphosis in MMI-treated larvae contributed to this observed toxicity. Further studies establishing a dose-response curve for MMI are required to completely assess the capability of MMI to induce lamprey metamorphosis.

The observed differences in the incidence of induced metamorphosis in the various goitrogen treatment groups (Fig. 2) can be correlated, to some extent, to the efficacy of each goitrogen at lowering serum TH concentrations. Following only 6 weeks of treatment, L-MMI and H-MMI induced proportionally more larval sea lampreys to enter metamorphosis than either the $\mathrm{H}-\mathrm{KClO}_{4}$ or $\mathrm{H}$ KSCN treatments. At the termination of Experiment 3 , the $\mathrm{H}-\mathrm{KClO}_{4}$ and $\mathrm{H}-\mathrm{KSCN}$ treatment groups were the most successful at inducing sea lamprey metamorphosis. These treatments $(\mathrm{H}-$ $\left.\mathrm{KClO}_{4}, \mathrm{H}-\mathrm{KSCN}, \mathrm{MMI}\right)$ that resulted in a high incidence of induced metamorphosis were also the experimental groups in which we measured the lowest serum TH concentrations (Fig. 3).

Following 6 weeks of treatment, MMI larvae had serum $\mathrm{T}_{4}$ concentrations which were as low or lower than larvae exposed to any other goitrogen treatment for 16 weeks (Fig. 3A). Furthermore, 6 weeks of MMI treatment produced serum $\mathrm{T}_{3}$ concentrations that were significantly lower than those in all other experimental groups except the $\mathrm{H}-\mathrm{KClO}_{4}$ experimental group (Fig. 3B). $\mathrm{H}-\mathrm{KClO}_{4}$ treatment induced precocious metamorphosis in more sea lampreys than any other experimental group; serum $\mathrm{TH}$ concentrations in this and the MMI experimental groups were the lowest measured in Experiment 3 (Fig. 3). Along these same lines of reasoning, we measured higher serum TH concentrations in those experimental groups in which a lower incidence of metamorphosis was observed. The lowest incidence of metamorphosis was observed in the $\mathrm{L}-\mathrm{KClO}_{4}$ and
L-KSCN treatment groups. Larvae in these two experimental groups had mean serum $\mathrm{T}_{3}$ concentrations which did not differ significantly from control values (Fig. 3B) and in the LKSCN experimental group serum $\mathrm{T}_{4}$ concentrations were also equivalent to values in the control group (Fig. 3A). The results of Experiment 3 confirm that goitrogens other than $\mathrm{KClO}_{4}$ can induce precocious metamorphosis in larval sea lampreys. Furthermore, the proportion of goitrogen-treated lampreys which were induced to metamorphose appeared to be correlated to the degree of the decline in serum $\mathrm{TH}$ concentrations; this finding differs from that reported by Youson et al. ('95) for $\mathrm{KClO}_{4}$-treated larval sea lampreys of different sizes.

Potassium is a component of two of the goitrogens $\left(\mathrm{KClO}_{4}\right.$ and $\left.\mathrm{KSCN}\right)$ that induce precocious metamorphosis in lampreys. This ion has been shown to induce metamorphosis in several invertebrate species (from five different phyla) including some protochordates (i.e., ascidians) (Yool et al., '86; Pearce and Scheibling, '94; Degnan et al., '97). Modern protochordates and vertebrates are both members of the phylum Chordata and are believed to have a complex evolutionary relationship (Whittaker, '97). One feature consistent with a common ancestry in protochordates and vertebrates is the presence of an endostyle in both larval lampreys and protochordates. The endostyle of larval lampreys is a TH-producing, subpharyngeal gland that develops into typical, follicular, thyroid tissue during metamorphosis (Wright and Youson, '80). In contrast, the endostyle of protochordates is primarily involved in producing mucus to aid in filter feeding. However, like the larval lamprey endostyle, the protochordate endostyle can actively concentrate iodide and synthesize iodoproteins and TH (Eales, '97). The finding that $\mathrm{K}^{+}$can induce metamorphosis in protochordates necessitated eliminating the possibility that it may have a role in the induction of lamprey metamorphosis (via $\mathrm{KClO}_{4}$ and $\mathrm{KSCN}$ ). Experiment 4 was designed to ensure that goitrogen-induced metamorphosis in sea lampreys was due to the goitrogenic anion (i.e., $\mathrm{ClO}_{4}^{-}$or $\mathrm{SCN}^{-}$) and not to the effects of $\mathrm{K}^{+}$. $\mathrm{A} \mathrm{NaClO}_{4}$ experimental group was also included to verify that the observed effects were not related to an interaction between the effects of $\mathrm{K}^{+}$and the goitrogenic anion.

Treatment with $18 \mathrm{mM} \mathrm{KCl}$ resulted in the death of all sea lampreys within 4 days. The high mortality rate within this treatment group may be related to an increase in the osmolarity of the 
aquarium water. In general, larval lampreys cannot osmoregulate even in dilute seawater (i.e., $10 \%$ NaCl; Mathers and Beamish, '74), and potassium ions may exacerbate this osmoregulatory difficulty. Death was not observed in any other experimental group over the course of Experiment 4. In the $\mathrm{L}-\mathrm{KCl}$ experimental group larvae were exposed to $3.6 \mathrm{mM} \mathrm{KCl}$, the same concentration of $\mathrm{K}^{+}$that is present in a $0.05 \% \mathrm{KClO}_{4}$ treatment. At this concentration, $\mathrm{KCl}$ had no effects on either the incidence of metamorphosis or serum $\mathrm{TH}$ concentrations (Figs. 4 and 5). However, serum $\mathrm{TH}$ concentrations in the $\mathrm{KClO}_{4}$ and $\mathrm{NaClO}_{4}$ experimental groups were significantly lower than all other experimental groups (Fig. 5). Associated with these declines in serum $\mathrm{TH}$ concentrations was an induction of metamorphosis. In both the $\mathrm{KClO}_{4}$ and $\mathrm{NaClO}_{4}$ experimental groups, we observed that $33 \%$ and $89 \%$ of all sea lampreys had initiated metamorphosis in the $110-119 \mathrm{~mm}$ and $>119 \mathrm{~mm}$ size groups, respectively (Fig. 4). This experiment has shown that $\mathrm{NaClO}_{4}$ has the same effects as $\mathrm{KClO}_{4}$ on both serum $\mathrm{TH}$ concentrations and metamorphosis, whereas $\mathrm{KCl}$ had neither of these effects. These results clearly indicate that $\mathrm{ClO}_{4}^{-}$, and not $\mathrm{K}^{+}$, is the ion responsible for depressing serum $\mathrm{TH}$ concentrations and inducing metamorphosis in lampreys.

In summary, the present results show that the induction of precocious metamorphosis in larval sea lampreys is associated with a decline in serum $\mathrm{TH}$ concentrations following treatment with a goitrogen. The incidence of goitrogen-induced metamorphosis in sea lampreys is related to the ability of the goitrogen to lower serum TH concentrations, further supporting the claim by Manzon et al. ('98) that $\mathrm{KClO}_{4}$-induced metamorphosis requires a decline in serum $\mathrm{TH}$ concentrations. Despite the absence of metamorphosis following PTU treatment, we feel that the induction of metamorphosis is a response to goitrogens in general and is not dependent on the mechanism by which a goitrogen reduces the capacity to synthesize TH. This idea is supported by the observation that MMI, a thyroid peroxidase-inhibiting goitrogen, can induce lamprey metamorphosis. PTU may be unique among goitrogens because it does not appear to induce lamprey metamorphosis; however, further studies using PTU concentrations that depress serum TH concentrations in sea lampreys are required to confirm this finding. Lastly, we have shown that $\mathrm{K}^{+}$ does not play a role in $\mathrm{KClO}_{4^{-}}$or $\mathrm{KSCN}$-induced metamorphosis.

\section{ACKNOWLEDGMENTS}

This research was supported in part by a Natural Sciences and Engineering Research Council of Canada (NSERC) postgraduate scholarship and an Ontario Graduate Scholarship (to R.G.M.). The authors thank Nancy Manjovski, Lori-Ann Manzon, Preshi Shanmugathasan, and Brian Peck for their technical assistance.

\section{LITERATURE CITED}

Brown DD. 1997. The role of thyroid hormone in zebrafish and axolotl development. Proc Natl Acad Sci USA 94:1301113016

Degnan BM, Souter D, Degnan SM, Long SC. 1997. Induction of metamorphosis with potassium ions requires development of competence and an anterior signaling center in the ascidian Herdmania momus. Dev Genes Evol 206:307-376.

Dodd MHI, Dodd JM. 1976. The biology of metamorphosis. In: Lofts B, editor. Physiology of the amphibia, Vol III. New York: Academic Press. p 467-599.

Eales JG. 1997. Iodine metabolism and thyroid-related functions in organisms lacking thyroid follicles: are thyroid hormones also vitamins? Proc Soc Exp Biol Med 214:302-317.

Eales JG, Holmes JA, McLeese JM, Youson JH. 1997. Thyroid hormone deiodination in various tissues of larval and upstream-migrant sea lampreys, Petromyzon marinus. Gen Comp Endocrinol 106:202-210.

Eales JG, McLeese JM, Holmes JA, Youson JH. 2000. Changes in intestinal and hepatic thyroid hormone deiodination during spontaneous metamorphosis of the sea lamprey, Petromyzon marinus. J Exp Zool 286:305-312.

Galton VA. 1983. Thyroid hormone action in amphibian metamorphosis. In: Oppenheimer JH, Samuels HH, editors. Molecular basis of thyroid hormone action. Toronto: Academic Press. p 445-483.

Gentile F, Di Lauro R, Salvatore G. 1995. Biosynthesis and secretion of thyroid hormones. In: DeGroot LJ, Besser M, Burger HG, Jameson JL, Loriaux DL, Marshall JC, Odell WD, Potts JT, Rubenstein AH, editors. Endocrinology, 3rd edition, Vol 1. Toronto: W.B. Saunders Company. p 517-542.

Gudernatsch JF. 1912. Feeding experiments on tadpoles. I. The influence of specific organs given as food on growth and differentiation. A contribution to the knowledge of organs with internal secretion. Arch Entwicklungsmech Org 35:457-483.

Hoheisel G, Sterba G. 1963. Über die Wirkung von Kaliumperchlorat $\left(\mathrm{KClO}_{4}\right)$ auf Ammocoeten von Lampetra planeri. Bloch Z Mikrosk Anat Forsch 70:490-516.

Holmes JA, Youson JH. 1993. Induction of metamorphosis in landlocked sea lampreys, Petromyzon marinus. J Exp Zool 267:598-604.

Holmes JA, Chu H, Khanam SA, Manzon RG, Youson JH. 1999. Spontaneous and induced metamorphosis in the American brook lamprey, Lampetra appendix. Can J Zool 77:959-971.

Inui Y, Miwa S, Yamano K, Hirano T. 1994. Hormonal control of flounder metamorphosis. In: Davey KG, Peter RE, Tobe SS, editors. Perspectives in comparative endocrinology. Ottawa: National Research Council of Canada. p 408-411.

Just JJ, Kraus-Just J, Check DA. 1981. Survey of chordate metamorphosis. In: Gilbert LI, Frieden E, editors. Meta- 
morphosis: a problem in developmental biology, 2nd edition. New York: Plenum Press. p 265-326.

Leatherland JF, Hilliard RW, Macey DJ, Potter IC. 1990. Changes in serum thyroxine and triiodothyronine concentrations during metamorphosis of the Southern Hemisphere lamprey Geotria australis, and the effect of propylthiouracil, triiodothyronine and environmental temperature on serum thyroid hormone concentrations of ammocoetes. Fish Physiol Biochem 8:167-177.

Lintlop SP, Youson JH. 1983. Concentrations of triiodothyronine in the sera of the sea lamprey, Petromyzon marinus, and the brook lamprey, Lampetra lamottenii, at various phases of the life cycle. Gen Comp Endocrinol 49:187-194.

Manzon RG, Youson JH. 1997. The effects of exogenous thyroxine $\left(\mathrm{T}_{4}\right)$ or triiodothyronine $\left(\mathrm{T}_{3}\right)$, in the presence and absence of potassium perchlorate, on the incidence of metamorphosis and on serum $\mathrm{T}_{4}$ and $\mathrm{T}_{3}$ concentrations in larval sea lampreys (Petromyzon marinus L.). Gen Comp Endocrinol 106:211-220.

Manzon RG, Youson JH. 1999. Temperature and $\mathrm{KClO}_{4}$-induced metamorphosis in the sea lamprey (Petromyzon marinus). Comp Biochem Physiol 124C:253-257.

Manzon RG, Eales JG, Youson JH. 1998. Blocking of $\mathrm{KClO}_{4}$ induced metamorphosis in premetamorphic sea lampreys by exogenous thyroid hormones (TH); effects of $\mathrm{KClO}_{4}$ and $\mathrm{TH}$ on serum TH concentrations and intestinal thyroxine outer-ring deiodination. Gen Comp Endocrinol 112:54-62.

Mathers JS, Beamish FWH. 1974. Changes in serum osmotic and ionic concentration in landlocked Petromyzon marinus. Comp Biochem Physiol 49A:677-688.

Pearce CM, Scheibling RE. 1994. Induction of metamorphosis of larval echinoids (Strongylocentrotus droebachiensis and Echinarachnius parma) by potassium chloride ( $\mathrm{KCl})$. Invertebr Reprod Dev 26:213-220.

Potter IC, Wright GM, Youson JH. 1978. Metamorphosis in the anadromous sea lamprey, Petromyzon marinus L. Can J Zool 56:561-570.

Sokal RR, Rohlf FJ. 1981. Biometry. New York: W.H. Freeman. p 859

Suzuki S. 1986. Induction of metamorphosis and thyroid function in the larval lamprey. In: Mederios-Neto G, Gaitan E, editors. Frontiers in thyroidology, Vol I. New York: Plenum Press. p 667-670.

Suzuki S. 1987. Induction of metamorphosis and thyroid func- tion in the larval lamprey. Proc First Congr Asia Oceania Soc Comp Endocrinol 1:220-221.

Suzuki S. 1989. Why goitrogens are chemical triggers of metamorphosis in the lamprey; relationship between thyroid function and metamorphosis. Gen Comp Endocrinol $74: 277$.

White BA, Nicoll CS. 1981. Hormonal control of amphibian metamorphosis. In: Gilbert LI, Frieden E, editors. Metamorphosis: a problem in developmental biology, 2nd edition. New York: Plenum Press. p 265-326.

Whittaker JR. 1997. Chordate evolution and autonomous specification of cell fate: the ascidian embryo model. Am Zool 37:237-249.

Wright GM, Youson JH. 1977. Serum thyroxine concentrations in larval and metamorphosing anadromous sea lamprey, Petromyzon marinus L. J Exp Zool 202:27-32.

Wright GM, Youson JH. 1980. Transformation of the endostyle of the anadromous sea lamprey, Petromyzon marinus L., during metamorphosis. II. Electron microscopy. J Morphol 166:231-257.

Yool AJ, Grau SM, Hadfield MG, Jensen RA, Markell DA, Morse DE. 1986. Excess potassium induces larval metamorphosis in four marine invertebrate species. Biol Bull 170: $255-266$.

Youson JH. 1997. Is lamprey metamorphosis regulated by thyroid hormones? Am Zool 37:441-460.

Youson JH, Potter IC. 1979. A description of the stages in the metamorphosis of the anadromous sea lamprey, Petromyzon marinus L. Can J Zool 57:1808-1817.

Youson JH, Plisetskaya EM, Leatherland JF. 1994. Concentrations of insulin and thyroid hormones in the serum of landlocked sea lampreys (Petromyzon marinus) of three larval year classes, in larvae exposed to two temperature regimes, and in individuals during and after metamorphosis. Gen Comp Endocrinol 94:294-304.

Youson JH, Holmes JA, Leatherland JF. 1995. Serum concentrations of thyroid hormones in $\mathrm{KClO}_{4}$-treated larval sea lampreys (Petromyzon marinus L.). Comp Biochem Physiol $111 \mathrm{C}: 265-270$

Youson JH, Manzon RG, Peck BJ, Holmes JA. 1997. Effects of exogenous thyroxine $\left(\mathrm{T}_{4}\right)$ and triiodothyronine $\left(\mathrm{T}_{3}\right)$ on spontaneous metamorphosis and serum $\mathrm{T}_{4}$ and $\mathrm{T}_{3}$ levels in immediately premetamorphic sea lampreys, Petromyzon marinus. J Exp Zool 279:145-155. 